\title{
FONG BOW'S FILE: CHINESE EXCLUSION AND RESISTANCE
}

\author{
Wendy Rouse \\ San Jose State University
}

Several years ago while conducting research at the National Archives at San Bruno, I had the opportunity to examine the case files of Chinese immigrant children who attempted to enter the United States under the Chinese Exclusion Act (1882-1943). These case files were riveting because each one detailed a complicated and deeply personal story of a child who had made great sacrifices to improve their situation and secure a future for themselves and their family. Of the hundreds of case files I examined, one struck me as particularly interesting. Removing the staples that had been used to seal the document over 100 years ago, I could not help but feel the thrill of discovery that comes with looking at a document from another era. I felt compelled to know more about the boy who stared back at me from a photograph that recalled a painful period in U.S. history. Although the thin and fragile papers disclosed only fragments of the life story of a fifteen-year-old boy named Fong Bow, they revealed even more about the story of U.S. immigration policy and Chinese Exclusion. Years after I finished my research, his photograph still lingered in my memory. I wrote this lesson so that his story and thousands like it would be remembered.

The story of Fong Bow helps to engage students in the study of history by asking them to consider the perspectives of past people and frame individual stories within the larger historical context. Through the process, students practice a method of inquiry similar to that used by professional historians and practice contextualizing and corroborating historical evidence. I have used this lesson in both high school and university classrooms. The personal story of an individual immigrant draws students into the lesson and engages them in the inquiry process. In the university setting this lesson may be presented as a primary source workshop following a discussion on urbanization, industrialization, and immigration in the nineteenth century. The lesson provides an opportunity to practice historical inquiry and to discuss the development of United States immigration policy into the twentieth century. For secondary school teachers, the content aligns with state content standards tied to immigration, and the skills addressed in this lesson specifically correlate to the new Common Core Reading Standards. In the College and Career Readiness Anchor Standard for Reading (R.CCR.1), students are asked to "read closely to determine what the text says explicitly and to make logical inferences from it; cite specific textual evidence when writing or speaking to support conclusions drawn from the text." In R.CCR.9, students are asked to "analyze how two or more texts address similar themes or topics in order to build 
knowledge or to compare the approaches the authors take." Dimension 3 of the College, Career and Civic Life (C3) Framework for Social Studies similarly prompts students to develop evidence-based claims by critically evaluating evidence and using evidence to structure claims. ${ }^{2}$ Whether used at the high school level or in an undergraduate survey, this lesson requires students to make logical inferences from the documents, cite textual evidence to support their conclusions, and sort through conflicting information to determine where the documents agree and disagree. Students will also have the opportunity to practice important historical thinking skills such as contextualizing sources, weighing historical evidence, considering historical perspective, and corroborating sources. ${ }^{3}$

The overarching guiding question in this lesson prompts students to consider how the individual story of Fong Bow ties into the larger narrative of the nation's immigration history. Students are asked: What were the experiences of Chinese immigrants who attempted to gain entry to the United States during the era of the Exclusion Act? How did immigrants and their families resist the Chinese Exclusion Act? Through the process of examining individual documents, students are prompted to source and contextualize the evidence, asking when and where a document was created, by whom, and for what purpose. Students are also prompted to corroborate the evidence by comparing the similarities and discrepancies in the testimony. In the end, students are asked to consider the individual perspective of Fong Bow and his family and their efforts to resist discriminatory immigration policies.

The story of Fong Bow is especially interesting to young learners as an opportunity to learn about a historical event from the perspective of another young person. Students are often more easily able to identify with the thoughts and feelings of a youth their age undergoing an ordeal like this than they are in reading the

\footnotetext{
${ }^{1}$ National Governors Association Center for Best Practices, Council of Chief State School Officers, Common Core State Standards for English Language Arts and Literacy in History/Social Studies, Science, and Technical Subjects (Washington, DC: National Governors Association Center for Best Practices, Council of Chief State School Officers, 2010). Available online at http://www.corestandards. org/wp-content/uploads/ELA_Standards1.pdf; California Department of Education, History-Social Science Content Standards for California Public Schools Kindergarten Through Grade Twelve (Sacramento, CA: California Department of Education Press, 2000); California Department of Education, 2016 History-Social Science Framework, adopted by the State Board of Education on July 14, 2016, available at http://www.cde.ca.gov/ci/hs/cf/sbedrafthssfw.asp.
}

\footnotetext{
${ }^{2}$ National Council for the Social Studies, The College, Career, and Civic Life (C3) Framework for Social Studies State Standards: Guidelines for Enhancing the Rigor of K-12 Civic, Economics, Geography, and History (Silver Spring, MD: National Council for the Social Studies, 2013).
}

\footnotetext{
${ }^{3}$ For more on the importance of historical thinking see Sam Wineburg, Historical Thinking and Other Unnatural Acts: Charting the Future of Teaching the Past (Philadelphia: Temple University Press, 2001 ); Peter Stearns, Peter Seixas, and Sam Wineburg, eds., Knowing, Teaching and Learning History: National and International Perspectives (New York: New York University Press, 2000).
} 
perspective of an adult. It is also important to recognize the role of children and youth as active participants in historical events and shapers of history. ${ }^{4}$

The lesson begins with an introduction to the history of the immigration station on Angel Island. The purpose of the introduction is to help situate students in the historical moment and identify somewhat with the emotions and experiences of the individuals who lived through this period of history. The immigration station and barracks were built in 1910 to house immigrants while their cases were under review by immigration authorities. Approximately half a million immigrants, mostly new arrivals from Asia, passed through Angel Island. The barracks at Angel Island continued to function as an immigration station until 1940. Abandoned and dilapidated, the buildings were slated for destruction in 1970 when a park ranger pointed out the potential significance of historic graffiti carved into the walls. After careful study of the inscriptions, experts determined that the carvings were actually poems written on the walls by the Chinese immigrants who were detained at Angel Island. Because of the historical importance of these poems, the barracks were saved from destruction. The instructor should explain to students that the poems they will read are translations of the actual poems at Angel Island. ${ }^{5}$

Students then participate in a gallery walk, rotating around the room examining the poetry on the walls and identifying textual evidence that reveals the underlying emotions conveyed in each of the poems. Students are also prompted to consider why the immigrants were experiencing these emotions, using evidence from the poems to support their inference. The following poems represent a sample of the sources the instructor may wish to include in the gallery walk:

America has power, but not justice.

In prison, we were victimized as if we were guilty.

Given no opportunity to explain, it was really brutal.

I bow my head in reflection but there is nothing I can do.

I am distressed that we Chinese are in this wooden building.

It is actually racial barriers which cause difficulties on Yingtai Island.

${ }^{4}$ Elliott West and Paula Petrik, Small Worlds: Children \& Adolescents in America 1850-1950 (Lawrence, KS: University Press of Kansas, 1992).

Sr"Station History," Angel Island Immigration Station Foundation website, 2016, http://www.aiisf.org/ education/station-history. For a thorough history of the Angel Island immigration station see Erika Lee and Judy Yung, Angel Island: Immigrant Gateway to America (New York: Oxford University Press, 2010). 
Even while they are tyrannical they still claim to be humanitarian.

I should regret my taking the risks of coming in the first place.

Instead of remaining a citizen of China, I willingly became an ox.

I intended to come to America to earn a living.

The western styled building are lofty; but I have not the luck to live in them.

How was anyone to know that my dwelling place would be a prison. ${ }^{6}$

Once students have completed the gallery walk and begin returning to their seats, the instructor posts the following quote and question on the board:

Give me your tired, your poor,

Your huddled masses yearning to breathe free,

The wretched refuse of your teeming shore.

Send these, the homeless, tempest-tost to me,

I lift my lamp beside the golden door!

- Colossus by Emma Lazarus, inscribed on the Statue of Liberty

Question: Is there a contradiction between the message in the Lazarus poem and the message in the poems you have read?

Following the reflection time, the instructor leads students through a group discussion asking them to identify the emotions that they encountered in the poems. The teacher should then ask students why they believe the immigrants were expressing these specific emotions. With both prompts, students should be reminded to provide textual support for their claims and to build on the ideas of their peers. Next, the instructor prompts students to share their thoughts on whether there is a contradiction between ideas espoused in the Lazarus poem and the emotions expressed in the Angel Island poems that they read. Students should once again back up their assertions with evidence and expand on the ideas presented by their peers. The instructor may also choose to lengthen this discussion into a two-day lesson plan in order to conduct a more in-depth close reading of one or more of the poems. By closely examining the poem 
structure and the figurative language, students may practice deconstructing these complex sources. ${ }^{7}$

Following the poetry discussion, the instructor should provide more historic context for the poems and the era of Chinese Exclusion. I have found that at this point students tend to express surprise at the intensity and range of emotions in the poems. This provides a good basis of discussion for the diversity of experiences of Chinese immigrants arriving in the United States during the Exclusion Era. Students should understand that beginning in the mid-1870s a powerful anti-Chinese movement emerged in California and the Pacific Northwest. Following an economic depression that led to substantial job loss for many, working-class whites blamed the economic recession on the "other" and projected their anger on a statistically small class of Chinese laborers living in major West coast cities like San Francisco. The Workingmen's Party of California rose to power with the slogan "The Chinese Must Go." At the federal level, they succeeded in lobbying Congress to pass laws limiting the immigration of Chinese laborers. The Chinese Exclusion Act of 1882 was a discriminatory law designed to keep immigrants out of the United States based solely on their race and social class. The law only applied to Chinese laborers, excluding them from entry into the United States. However, exemptions to the Exclusion Act allowed merchants, merchant families, teachers, students, native (American-born) Chinese, or the children of natives to be admitted into the country. This was the first major law to deny entrance to a group of immigrants based primarily on their race and socioeconomic status, setting a precedent for future discriminatory immigration laws. Chinese immigrants were detained on Pier 40 in San Francisco and later at Angel Island while immigration inspectors interviewed witnesses and questioned immigrants to determine if they qualified for entry. A thriving illegal immigration network emerged to circumvent the Chinese Exclusion Act. Under the paper son/paper daughter system, immigrants sometimes pretended to be the son or daughter of a Chinese merchant or native already living in the United States. In response to the increasing number of paper sons and daughters, the government began asking more intense and detailed questions. If, after interrogation and witness statements, immigration officials believed that the individual was actually related to the alleged father, they could gain admittance to the United States. ${ }^{8}$

${ }^{7}$ This online lesson plan walks students through a close reading of the Angel Island poems: "Discovering Angel Island: The Story Behind the Poems," Lesson Unit 1, KQED Education Network, School Services: Asian Education Initiative.

${ }^{8}$ For historic context on Chinese Exclusion and Angel Island see Erika Lee, At America's Gates: Chinese Immigration During the Exclusion Era, 1882-1943 (Chapel Hill: University of North Carolina Press, 2003); Lucy E. Sayler, Laws Harsh as Tigers: Chinese Immigrants and the Shaping of Modern Immigration Law (Chapel Hill: University of North Carolina Press, 1995); Erika Lee and Judy Yung, 
Following the contextual discussion, the instructor should introduce students to the problem-solving group work activity by explaining that they will be asked to examine an original case file of a Chinese immigrant who arrived in San Francisco during the era of Chinese Exclusion. Fifteen-year old Fong Bow left his mother and younger brother in China to join his father in San Francisco in 1909. Fong Bow arrived the year before the immigration station at Angel Island was opened, but he was still detained by immigration officials for over a month with many other Chinese immigrants at the detention shed at Pier 40. Fong Bow told immigration officials that he came to California to live with his father, Fong Lung, who was a fruit gardener in Isleton, California. Since Fong Lung was born in California, Fong Bow was claiming the right to entry under the exempt-status of "son of a Native." In this lesson, students will assume the role of a historical detective and try to determine for themselves if Fong Bow was a paper son. Regardless of whether or not Fong Bow was actually the son of Fong Lung, his family had clearly invested a great deal and taken many risks to secure a better future for Fong Bow in the United States. The Chinese Exclusion Act represented a formidable barrier that discriminated against working-class Chinese immigrants like Fong Bow. Therefore, students will be asked to consider the effect of the Chinese Exclusion Act on individuals and the ways in which Chinese immigrants like Fong Bow attempted to circumvent the discriminatory law.

Students will begin by examining the interrogation records of both Fong Bow and his father, Fong Lung (Appendix A). ${ }^{9}$ Students will source the documents, particularly noting when, where, and in what context each of the documents was created. In responding to these questions, students will notice that the interviews of father and son took place on different days (eight days apart), and that Fong Bow was called back again six days after the inspectors interviewed his father in order to answer additional questions. A careful observation of the context of the interviews will reveal that an immigration inspector led the interview with the assistance of an interpreter. A stenographer was also present to transcribe the conversation on a typewriter. This is important information for students to note in evaluating the credibility of the statements later in their analysis. The instructor should also prompt students to consider the historical context of the documents in order to better understand what is happening in this case. The instructor might also point out that Fong Bow arrived after U.S. v. Ju Toy (1905). This U.S. Supreme Court decision held that a Chinese immigrant who was denied entry by immigration officials could no longer file an appeal through the court

${ }^{8}($...continued $)$

Angel Island: Immigrant Gateway to America.

${ }^{9}$ Digital pdf files of the original documents and analysis guides for student use are available through Teaching History's website at: openjournals.bsu.edu/teachinghistory or by contacting the author at wendy.rouse@sjsu.edu. 
system. Instead, all appeals had to be filed through the immigration department itself. In effect, this decision limited the options available to immigrants who wished to challenge exclusion. It also meant that the Immigration Bureau's decisions were in most cases no longer subject to judicial review. After the $J u$ Toy decision in 1905, the Immigration Bureau retained greater power to restrict Chinese immigrants and used their authority to deny admission to more applicants. ${ }^{10}$

After sourcing the document, students will examine the documents much more closely and begin to corroborate the sources. Readers are prompted to note similarities and discrepancies in the testimony between father and son. Students are asked to account for some of the discrepancies by considering what they learned in sourcing the documents and about the context in which the interviews were conducted and how this may have impacted the interviewers and interviewees. For example, individuals may note that the environment would have been extremely stressful for interviewees given the presence of three immigration officials and the importance of the interviews in determining their admission. Children like Fong Bow may have felt especially intimidated by the questions and may have made mistakes. Students may also note that mistakes could have been made in the interpretation and/or transcription, or conversely, they may point out the professional training of the interviewers and the presence of three people attesting to the validity of what was transcribed. Students sometimes point to specific questions that Fong Bow should have known if he were indeed the son of Fong Lung. In weighing the validity of the evidence, students should provide specific textual evidence to back their claims. Students may weigh this evidence to consider whether or not Fong Bow was a paper son.

After students have made tentative conclusions, the instructor should introduce additional evidence in the form of four photographs that were taken of Fong Bow and his father during the immigration process. " Fong Bow's attorneys requested the photographs be taken for the purpose of supporting his appeal and proving that he was in fact the son of Fong Lung. This was an additional step on the part of Fong Bow's family to prove his identity and right to enter the United States. ${ }^{12}$ Students are asked to consider this fact as well as examine the actual photos to determine if the two individuals could be related. At this point, students may express their opinion regarding the physical similarities of Fong Bow and Fong Lung by pointing to evidence in the photographs themselves.

${ }^{10}$ Lucy E. Sayler, Laws Harsh as Tigers, 121-139.

"Digital copies of the photographs are available through Teaching History's website at: openjournals.bsu.edu/teachinghistory or by contacting the author at wendy.rouse@sjsu.edu.

\footnotetext{
${ }^{12}$ For more information on the ways in which Chinese immigrants used photography to challenge the exclusion laws see Anna Pegler-Gordon, In Sight of America: Photography and the Development of U.S. Immigration Policy (Berkeley: University of California Press, 2009).
} 
More important, however, than the question of whether or not Fong Bow was a paper son, is the idea that the immigration policies were unfairly biased against Chinese laborers based on their race and class and that Chinese immigrants went to great lengths to resist the discriminatory laws. Individual immigrants challenged the system and were willing to take great risks through the paper son system in order to try to bypass Chinese Exclusion. The students are asked to go back to the documents and think about why individuals might still try to immigrate to the United States after the passage of the Chinese Exclusion Act. Students are also prompted to consider how the Chinese Exclusion Act unjustly discriminated against individuals like Fong Bow. Students are also asked to consider the various ways that Fong Bow and his family fought the unjust law by 1) making the investment and taking the risk to send Fong Bow to the United States, 2) presenting witnesses to testify on his behalf, 3) hiring an attorney to file an appeal to the immigration official's decision, 4) hiring a photographer to take photographs to try to prove that they were father and son. If Fong Bow was a paper son, then the paper son system was yet a fifth way that Chinese immigrants attempted to bypass the Exclusion Act. Students may also be able to deduce from the evidence or recall from their prior knowledge that some Chinese immigrants evaded immigration authorities and bypassed exclusion laws by coming into the country through Mexico or Canada. Chinese immigrants and Chinese Americans also filed challenges in the courts and sent petitions to the President to fight the discriminatory law. The government of China even instituted a boycott against American goods in protest of the treatment of Chinese immigrants in the United States. The teacher should explain that Chinese Exclusion officially ended in 1943 when China became our ally during World War II.

At the conclusion of the activity, students are often interested to learn about Fong Bow's fate. The docket sheet (Document $G$ ) reveals what happened in this case. In examining this document, students will notice that Fong Bow was held in detention for over a month as immigration officials considered his case. As they may recall from the poems, this experience was frightening, frustrating, and intimidating for many adult immigrants and most likely even more so for children like Fong Bow. Ultimately, immigration officials determined to deport Fong Bow, sending him back to China on the next available outbound ship. This must have been a devastating decision for Fong Bow and his family back home. After considering Fong Bow's case, students are asked to speculate why he (whether a paper son or not) would have gone to such great lengths to come to the United States especially given the intensity of the process and the potential for deportation. At this point, students should think about push factors that led many Chinese families to seek employment abroad and the pull factors that drew them to countries like the United States, Canada, and in Central and South America. Students should also consider what the impact of the decision to deport Fong Bow may have had on him and his family in China. Students should understand that the Exclusion Act unfairly targeted Chinese immigrants because of their race and class. Students should also understand that Chinese immigrants and Chinese Americans resisted the Exclusion Act by petitioning the President of the United States, challenging 
the constitutionality of the law, appealing to the Chinese government for help, and boycotting American goods. Individuals likewise challenged the law by appealing the immigration bureau's decisions in the courts, offering evidence of their familial relationship, and creating the paper son system. ${ }^{13}$

I frequently conclude the lesson with a formal written assignment or essay asking students to synthesize their knowledge on the topic and to examine the overall significance of the Chinese Exclusion Act both on individual immigrants and as a precedent for future immigration policy. After examining the case of Fong Bow, my students tend to have a much stronger understanding of the process and effects of Chinese Exclusion, especially from the perspective of an individual immigrant who directly experienced the implications of the policy. Through the practice of contextualization and corroboration in analyzing the file of Fong Bow, students gain knowledge about the importance of carefully sourcing and evaluating evidence. The final assessment question asks students to step back from the case of Fong Bow and individual documents to consider not only the significance of the Exclusion Act on Chinese immigrants, but its larger significance in shaping United States immigration policy to present day.

The case of Fong Bow provides an interesting history mystery and an introduction to the era of Chinese Exclusion. Students practice sourcing, contextualizing, and corroborating primary documents in an effort to better understand the human impact of America's exclusionary immigration policies. Students learn about the factors that motivated people to leave their homes and take the risk of immigrating to another country and the sacrifices that families made in an effort to improve their situation. The lesson also illuminates the complex network of individuals who came together as a community to resist the unjust Chinese Exclusion laws. The story of Fong Bow reveals the impact of discriminatory immigration policies on the lives of individuals and the reverberating impact of Chinese Exclusion on United States immigration policies in the twentieth century and beyond.

\footnotetext{
${ }^{13}$ For specific information on the experience of Chinese immigrant children see Wendy Rouse Jorae, Children of Chinatown: Growing Up Chinese American in San Francisco, 1850-1920 (Chapel Hill: University of North Carolina Press, 2009), 9-41.
} 


\section{APPENDIX A}

\section{Transcription of Document A}

On SS Siberia, of May 3009

63 , Fong Bow

Son of Native
June 209

Insp. Heitmann

Int. Jack

Sten. RTF

Applicant

Sworn

Q. What are your names, age and birthplace?

A. Fong Bow, no other name, not married, 15, born KS 21-2d 5-15 (July 7, 1895) in How Chung vill. Heong Shan dist. China (Satisfied as to age)

Q. How large is that village?

A. 400 or 500 houses

Q. Where is your house?

A. 2 alley, 2 house

Q. What is nearest market?

A. Seuk Kee $1 / 2$ li away [0.15 miles]

Q. What have you been doing in China?

A. Going to school, 12 yrs old till 14

Q. Who is your father?

A. Fong Lung, (recognizes photo) 31 - don't remember seeing him; laborer Suisun

Q. Who is your mother?

A. Lee Shee, bound $\mathrm{ft}$ [bound feet], 31, living

Q. Has your father more than one wife?

A. No

Q. Have you any brothers or sister?

A. One brother, no sisters: Fong Yuen, 14, in China at school

Sgd in Chin.

6-3-09 


\section{Transcription of Document B}

Chin. Divn. Y.S.

63 , Fong Bow

Son nat [Son of a native born American]

Siberia, May 3009
S.F.

June 1009

Insp. Heitmann

Int. Chin Ming

Sten. RTF

\section{$\mathrm{Al}$ father}

Sworn

Q. What are your names, age and birthplace?

A. Fong Lung; Fong Dok Sing, 31, born KS 5-7-15 [September 1, 1879] in San Francisco

Q. How many trips have you made to China?

A. One (CR 12312, USDC NDC went to China 1881, ret. Amer. Maru, Jan 23, 1901. As nat. [native born American] Photo OK)

Q. What do you do now?

A. Fruit gardener, Isleton

Q. Are you married?

A. Yes to Lee Shee, 31, nat. ft. [natural feet] living

Q. Did you ever have another wife?
A. No.
Q. When did you marry?
A. KS 20-4-8 [May 12, 1894] when 16 years old.
Q. Have you any children?

A. 2 boys, no girls: Fong Bow, 15 (recognizes photo) born KS 21-2d 5-15 [July 7, 1895]

Q. What has he been doing in China?

A. Went to school 11 or 12 yrs old till 14 ; then helped at home

Q. Next boy?

A. Fong Yeun, 14, born KS 22-9-19 [October 25, 1896] in China at school since 11 yrs old

Q. Is that all the children you have?

A. Yes

Q. Did you ever have any other children?

A. No.

Q. Where does your family live in China?

A. How Chung vill

Q. How large is that village?

A. 400 or 500 houses

$\mathrm{Q}$. Where is your house?

A. 2 alley, 2 house

Q. What is nearest market? 
A. Seuk Kee, 3 or 4 li away [0.9 to 1.2 miles]

Q. What is your father's name?

A. Fong Din Hong

Q. How old is he?

A. 58 or 59

Q. Is he living?

A. He died KS 30-6 [July 1904]

Q. Was he living at your house?

A. Yes

Q. What is your mother's name?

A. Ng Shee, bound $\mathrm{ft}$ [bound feet]

Q. Is she living?

A. She died KS 31-3 [April 1905] when 53 or 4 yrs old

Q. Did your mother and father live with your family in China?

A. Yes

Q. Do you remember being examined on your arrival Amer. Maru, Dec. 22, 1900 ?

A. Yes (Recognizes photograph on said papers as his own)

Q. (Testimony read to him and he acknowledges it as correct except: "Q Are you married? A No")

A. He didn't ask me if I was married. He asked me if I had brought my wife with me and I said "No."

Q. You can make any explanation now you see fit?

A. I was not asked if I was married?

Q. Have you anything further to state?

A. No

Q. Have you understood the interpreter?

A. Yes

Sgd

6-11-09

\section{Transcription of Document C}

Shed

63, Fong Bow

Son na [Son of a native born American]

Siberia, May 3009
June 1609

Insp. Heitmann

Int. Kay

Sten. RTF 
Q. What is your name and age?

A. Fong Bow, 15

Q. What is your paternal grandfather's name?

A. Fong Din Hong, 60 about

Q. Where is he?

A. Died KS 27 or 28 [1901 or 1902]

Q. Did he live at your house?

A. Yes

Q. What is your paternal grandmother's name?

A. $\mathrm{Ng}$ Shee, nat. $\mathrm{ft}$

Q. Where is she?

A. Died KS 27 or 28 [1901 or 1902]

Q. How old was she when she died?

A. Don't remember

Sgd

6-16-09

Transcription of Document D

NOTICE TO REJECTED CHINESE APPLICANT UNDER RULE 6 Department of Commerce and Labor IMMIGRATION SERVICE

Port of San Francisco

June 19, 1909

You are hereby notified that your application for admission to the United States is denied. From this decision you have the right of appeal to the Secretary of Commerce and Labor. If you desire to appeal, you must notify the officer in charge at this port within two days of the receipt of this notice.

[Chinese translation above] 


\title{
Transcription of Document E
}

\author{
FORM OF APPEAL
}

San Francisco, Cal., June 21, 1909

We hereby appeal to the Honorable Secretary of Commerce and Labor from the decision of the Commissioner of Immigration in Case No. 63, arriving ex S.S. Siberia on May $30^{\text {th }} 09$, and agree to perfect appeal within three days by filling brief with Dept. I will be represented before the Department by Attorney Ralston \& Siddons (No.) Bond Bldg. (St.) Wash. D.C.

McGowan \& Worley Attorney for Fong Bow

Appellant

\section{Transcription of Document $F$}

Alfred L. Worley

George A. McGowan

\author{
McGowan \& Worley \\ Attorneys and Counselors at Law \\ Bank of Italy Building \\ S.E. Cor. Montgomery and Clay Streets \\ Rooms 302, 303, and 304
}

Telephone Kearny 3092

San Francisco June $24^{\text {th }}, 1909$

Commissioner of Immigration

Port of San Francisco,

Dear Sir:-

In re Fong Bow, Citizen's minor son, No. 63

EX. S.S. Siberia, May $30^{\text {th }}, 1909$

In the above titled matter we would ask for an extension of two days time within which to have the applicant in the above entitled case photographed together with his father for the purpose of obtaining different views of them showing the physical resemblance. These photographs are to be taken by your official photographer and when the photographs are filed we would request that the case then be forwarded to the Department. 
Yours respectfully,

McGowan and Worley [signed]

Attys. Of Applicant

\author{
Jun 24, 1909 \\ ABOVE REQUEST GRANTED \\ CHARLES MAHAN \\ CHINESE INSPECTOR IN CHARGE
}

\title{
Transcription of Document G
}

Department of Commerce and Labor

Immigration Service

Dort of San Francisco, Cal.

Certif.: 63

Name: Fong Bow

Class: Son of Native

Place: Oakland, $\mathrm{Cal}$

Ex S.S.: Siberia May 30, 1909

Denied: June 19, 1909

Appealed: Jun 21, 1909

By Attorney: McGowan \& Worley

Represented before Department

By Ralston \& Liddons, Attorney

Sent to Dept. July 3, 1909

Appeal dismissed, telegram of Dept.

July 10, 1909

Departed from San Francisco Per Steamer Asia

July 10, 1909

Inspector 